\title{
Traditional Arabic and Islamic Medicine Primary Methods in Applied Therapy
}

\author{
Sara N. AlRawi ${ }^{1} \&$ Michael D. Fetters ${ }^{2}$ \\ ${ }^{1}$ Sara AlRawi Consulting, LLC, Ann Arbor, MI, U.S.A. \\ ${ }^{2}$ Department of Family Medicine, University of Michigan, Ann Arbor, MI, U.S.A. \\ Correspondence: Sara AlRawi, Sara AlRawi Consulting, LLC, Ann Arbor, MI 48104-1213, U.S.A. Tel: \\ 1-734-645-8424. E-mail: samis@umich.edu
}

Received: July 11, 2019 Accepted: August 11, 2019 Online Published: August 16, 2019

doi:10.5539/gjhs.v11n10p73

URL: https://doi.org/10.5539/gjhs.v11n10p73

\begin{abstract}
Applied therapy is a commonly utilized method of treatment for preventive and therapeutic measures. Avicenna, a significant physician of the Islamic golden age, described 36 methods to restore balance of patients' elements, humors and faculties. We propose a categorization of these methods within a single theory and framework, as this has previously been lacking. To be considered under the rubric of TAIM applied therapies, the procedures must have: 1) proof of use in the Arab and Muslim world; 2) considered an essential component of Avicenna's compendium of regimental therapy; and 3) historical lineage according to regional, cultural or Islamic healing practices. We developed a taxonomy of applied therapies by denoting each as a primary or supportive method and providing a definition for each category of methods. We define applied therapy as techniques or procedures involving physical and manual contact with the individual that are aimed at restoring health and preventing illness. Primary methods describe therapies which when used individually can impact the vital force of the body in order to preserve or restore health, while supportive methods describe therapies used in conjunction with primary methods intended to augment or create a synergistic and enhanced effect, exceeding that of primary methods alone. Our work provides a fundamental step in continuing the evolution of the TAIM conceptual model and advancing our understanding of the diverse practices under the rubric of applied therapy. Researchers can use this comprehensive TAIM taxonomy for investigating the respective elements, and systematically exploring the theoretical and therapeutic applications.
\end{abstract}

Keywords: aromatherapy, hammam, hijama, hydrotherapy, unani medicine, Avicenna

\section{Introduction}

The Traditional Arabic \& Islamic Medicine (TAIM) model was introduced to define and organize the multiple intertwined elements within a single conceptual framework (Alrawi \& Fetters, 2012). TAIM elements include medicinal herbs, dietary practices, mind-body therapy, spiritual healing and applied therapy. We define applied therapy as techniques or procedures involving physical and manual contact with the individual, aimed at restoring health and preventing illness. Applied therapies are among the most utilized methods of treatment employed by traditional physicians for preventive and therapeutic measures (Lone et al., 2011).

A taxonomy that unifies and demonstrates the depth and encapsulates the richness of the applied therapies specifically has been lacking. Absence of a systematic categorization, one that is cohesive and comprehensive, creates a barrier to the classification of applied methods and research investigating the prevalence of use. Thus, the primary objectives in this paper are: 1) to define and categorize in a taxonomy the applied therapy element of the TAIM model and contextualize its application within the scope of practice, and 2) to suggest a hierarchical organization of the methods utilized as primary or supportive. To achieve these objectives, we first review the historical context of applied therapies, and known extent of use. We then explain our methodology for creating a typology and describe each component of the typology based on known origins and current applications. We conclude with a discussion of the typology including potential limitations.

\subsection{History of Applied Therapy and Extent of Use}

Since the third millennium B.C., Arab and Muslim physicians have drawn on traditional practices in ancient Mesopotamia and ancient Babylon (De Bustinza, 2016). They have also practiced medicine with roots in 
Graeco-Roman, Chinese, Persian and Ayurvedic theories and principles. One of the most significant thinkers and writers of the Islamic golden age, Avicenna, believed that "medicine is the art whereby health is maintained and the art by which it is restored when lost" (p. 90) (M. A. Khan, Raza, \& I. A. Khan, 2015). Physicians believed in promotion of health, prevention of disease and restoration of health through regimental and dietary therapies (Lone et al., 2012). Avicenna described 36 methods to restore balance of patients' various elements, humors and faculties (Hamid, 2018). Arab and Muslim physicians such as Rhazes and Avicenna believed both physical and spiritual health is essential, that the body should be treated as a whole entity rather than separate parts and organs, and that the body possesses the natural ability to heal when provided with rest, a good diet, fresh air, and cleanliness (Saad \& Said, 2011). Illness is viewed as an opportunity to serve, clean, purify and balance the physical, emotional, mental and spiritual realms (Lone et al., 2012). This core belief can be seen weaved through the methods utilized for restoring and maintaining health.

Previous research demonstrates widespread use of applied therapies globally, (Hamid, 2018) yet a clear and encompassing definition and framework illuminating historical roots, religious influences and modern day applications is lacking. The clinical implications of defining the scope of applied therapy practices are to shed light on commonly utilized methods, demonstrate potential for integration of methods into health care needs, understand determinants of care as well as delineate patterns of utilization.

\section{Methods}

\subsection{Methodology for Creating the Typology}

For procedures to be considered under the rubric of TAIM applied therapies, we required: 1) proof of use in the Arab and Muslim world; 2) considered an essential component of Avicenna's compendium of regimental therapy; and 3) historical lineage according to regional, cultural or Islamic healing practices. General treatment objectives follow a three-step pattern specifying elimination of cause, normalization of humors, and normalization of tissues and or organs. We created a typology of primary and supportive methods to differentiate between the various therapies in their approach to modulate the patient's physical, mental, emotional, and spiritual health with the goal of restoring constitutional balance. We arrived at this categorization of primary and supportive methods based on careful examination of historical and current use, as well as physiological effect of each applied therapy. Figure 1 illustrates primary and supportive methods of the applied therapy element within TAIM.

\subsubsection{Primary Methods}

Primary methods describe therapies which when used individually can impact the vital force of the body in order to preserve or restore health and achieve the goals of recovery. These methods are often considered part of a standard set of treatments. Primary methods include leeching, venesection, cupping, manual therapy, cauterization, auricular therapy, fomentation, hydrotherapy, and physical movement. We grouped the aforementioned procedures under primary methods based on evidence of use in chronic and lifestyle mediated conditions including asthma, coronary heart disease, type 2 diabetes, digestive disorders, musculoskeletal concerns, rheumatoid arthritis, chronic skin disorders as well as autoimmune conditions. By virtue of their effect, procedures listed under primary methods are able to balance the elements inherent in every individual by manipulating innate or acquired, physical or energetic, deficiencies involving body, mind, and spirit. If primary methods are unable to produce a cure or cause unwarranted effects, supportive methods are employed.

\subsubsection{Supportive Methods}

Supportive methods describe therapies used in conjunction with primary methods and are intended to augment or create a synergistic and enhanced effect, which exceeds that of a primary method alone. As illustrated in Figure 1, examples include, purgation, emesis, diuresis, enema, diaphoresis, irrigation, expectoration, and counter irritation. Supportive measures are designed to further aid cleansing, balancing, healing, and rejuvenation if and when primary methods alone are unable to encourage the goals of recovery (Figure 1). We chose the term supportive rather than secondary to highlight the interconnectivity (as represented by the arrows in Figure 1) and sometimes promoting nature of these methods. We turn now to the role of primary methods and expound upon the understanding of the applied therapy element of the TAIM model. 

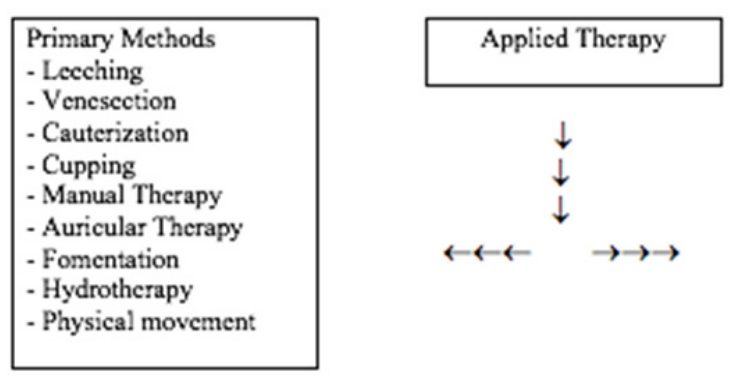

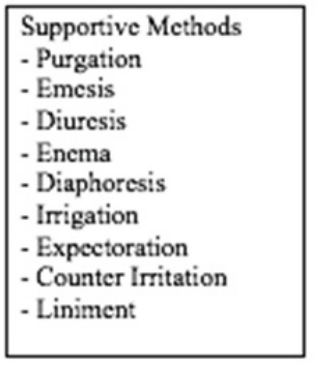

Figure 1. Hierarchical categorization of TAIM applied therapy

\subsection{Description of the Applied Therapy Typology Componenets}

Initial approaches to treatment entail the establishment of a regimen of care, or applied therapy, to correct and balance factors contributing to ill health. Should this initial course of treatment prove to be ineffective, only then are additional methods such as diet and natural medicine recommended. The safety and efficacy of applied therapies have been supported by scientific rigor, however additional studies are needed to standardize and develop parameters for evaluation of the efficacy of all procedures. Important techniques in applied therapy along with details regarding its principles, objectives, indications, clinical applications, and contraindications are described below.

\subsubsection{Leeching}

The Mesopotamians, Egyptians, Greeks, Mayans, and Aztecs practiced leech therapy (Lone et al., 2011). When Islamic medical theories began to disseminate through the Latin speaking countries of Europe, leech therapy became more widespread (Lone et al., 2011). Leech therapy, or Taleeq, relies on the application of medicinal leeches (Hirudo medicinalis) to an affected area to suck and draw the blood from deeper tissues (Ahmad \& Anwar, 2009). Avicenna described the methodlogy of leech therapy according to pre-leeching, proper leeching and post leeching procedures (Lone et al., 2011). During this process, leeches infuse their saliva into the blood, providing a complex mixture of biologically and pharmacologically active substances (Singh, 2010). Abdualkader, Ghawi, Alaama, Awang and Merzouk (2013) indicate that the important advantage of leech therapy is that it may be advised on those areas of the body where other processes of bloodletting like venesection and cupping are not possible.

Clinical applications. Jha, Garg, Narang and Das (2015) indicate the use of leech therapy in varicose veins, chronic skin disease, chronic ulcers, migraines, musculoskeletal and cardiovascular conditions. Contraindications reported by Parmar and Parmar (2014) include the treatment of medical conditions and diseases including hemorrhagic diseases, absolute hemophilia, pregnancy, anemia, hypotension, general fatigue, allergy to leech, active tuberculosis, immune compromised and severely ill, bed ridden and extremely fearful patients. Parmar and Parmar (2014) further suggest sites of the body where leech application is contraindicated such as the abdomen around the liver, spleen, stomach and intestine, and report the risk of adverse effects and complications such as pain during treatment, local itching, hypotension, vasovagal attacks, anemia, infections, allergies, sepsis, scarring, and slight fever.

\subsubsection{Venesection}

Venesection, or Faşd, originated in the ancient civilization of Egypt, then continued with the Greeks, Romans, Arabs, Asians, and eventually spread through Europe during the Middle Ages and the Renaissance (Greenstone, 2010). In this procedure, an incision is made in any of the 32 superficial vessels, and blood containing waste material is allowed to flow (Sherwani, A. N. Anasari, H. A. Anasari, \& I. A. J. A. Anasari, 2004). Historically, instruments used included thorns, sharp sticks, and pieces of shell (Bergum \& Ansari, 2012). Bloodletting is generally carried out from various veins and arteries; each providing a site for specific indications, i.e. cephalic vein used for diseases of the head and neck like meningitis, conjunctivitis and pain in the ear (Bergum \& Ansari, 2012). The practice of venesection was not recommended by the Prophet Muhammad which explains why general bloodletting was not a practice early Muslims implemented following the Prophet's death in 632 AD despite their awareness of it (El-Wakil, 2011). Bergum and Ansari (2012) considered spring as a suitable time for venesection.

Clinical applications. Faiz and Ali (2018) indicate the use of venesection for removing excess or abnormal humors, 
preventing accumulation of waste material in the blood, excreting waste material from various parts of the body, stimulating metabolic processes and correcting altered temperaments. Contraindications reported by Khan, Siddiqui, Itrat and Jamal (2014) include applying procedure in excessively cold temperament and climate, in cases of severe pain, after coitus, in children less than fourteen years of age, obesity, in elderly persons, with a full stomach, after resolving baths, and during pregnancy or menstruation.

\subsubsection{Cauterization}

Cauterization and the use of heat therapy were known to various ancient cultures including Egyptian, Indian, Chinese, Greco-Roman as well as pre- and post-Islamic and Arab culture (Alsanad, Asim, Gazzaffi, \& Qureshi, 2018). The use of cautery, or Kai, was greatly developed by the Arab Muslim physician Albucassis, who described various techniques, instruments, indications, precautionary measures, and related possible risks to more than 50 cauteries (Alsanad et al., 2018). The number of cautery events in one session vary, and the place of application is specific to each disease. Treatment further depends on the age and sex of the patient (Farid \& El-Mansoury, 2015). The instrument used for cauterization is called cautery or Mikwāt, and preferably made of gold or iron (Nasir, Fatma, Ali, \& Ahmad, 2018). In a prophetic tradition, it is narrated that the Prophet Muhammad performed cautery on one of his companions when he had sepsis on his finger, (Nikhat \& Fazil, 2013) and on another occasion to stop bleeding. However, it is believed that the Prophet allowed the use of cauterization only in severe cases, which has since been maintained according to Islamic law (El-Wakil, 2011). The Prophet advised against the use of cauterization as a routine procedure, and it's apparent that the practice of cupping was favored to cauterization following his teachings (El-Wakil, 2011).

Clinical applications. Nikhat and Fazil (2013) report the use of cauterization in five circumstances: "first to halt the spread of sepsis; second, to stop the flow of disease-causing humors toward the healthy areas; third, to correct the abnormal cold temperament in an organ; fourth, to stop hemorrhage, and fifth to remove dead and necrotic tissue when other methods are not effective" (p. 83). Indications for cauterization also include paralysis, recurrent cold and cough, migraine, musculoskeletal disorders, vascular bleeding, gangrene, moles, skin outgrowths, splenomegaly, and ascites. Cauterization is contraindicated in extremely cold or hot weather (Nasir, Fatma, Ali \& Ahmad, 2018). Following the procedure, patients are treated with herbal medicine and prescribed a specific diet to aid recovery.

\subsubsection{Cupping}

The earliest recorded references to cupping therapy are found in the Ebers Papyrus, dating back to 1550 B.C (Qureshi et al., 2017). Cupping therapy has roots among many ancient healing systems including Chinese, Unani, traditional Korean, Tibetan, African, European, Arabic and Prophetic medicine, with variations in the types of cups used, methods of cupping, and application sites (Mehta \& Dhapte, 2015). Cupping in Arabic is called Hijama, and derived from the Arabic word 'hajm', which means to suck something out, to collect, or to extract so as to restore something to its natural state (Qureshi et al., 2017). It is a technique in which a cup is applied over the surface of the skin by creating a vacuum--this is known as dry cupping or Hijāmat bilā Shart (Mehta \& Dhapte, 2015). Dry cupping can further be subdivided into two types: fire cupping and cupping without fire (Mohammad, Fasihuzzaman, \& Jabeen, 2015). Sometimes, scarification is done at the location of cupping to draw blood, this process is known as wet cupping or Hijämat bi'l-Shart (Mehta \& Dhapte, 2015). Wet cupping can further be subdivided into mandatory and optional, depending on the indication. According to Islamic tradition, hijama is usually explicit to 'blood cupping' (El-Wakil, 2011). Hijama was recommended by the prophet Muhammad, who mentioned cupping in approximately 28 holy instructions or hadith (Saqlain, Ali, \& Parveen, 2017). According to the teachings of the prophet, hijama is recommended on the 17th, 19th and 21 st of the month, according to the Islamic lunar calendar (Saqlain, Ali, \& Parveen, 2017). Various sites of the body are indicated for application of hijama (Mohammad, Fasihuzzaman, \& Jabeen, 2015). To date, this method of healing continues to thrive in many Muslim countries (Deuraseh, 2006).

Clinical applications. Ahmedi and Siddiqui (2014) report indications for cupping such as the elimination or diversion of morbid material, enhancing circulation, correcting the temperament of a particular organ and promoting detoxification. Qureshi et al., (2017) reports indication of cupping therapy for the treatment of many chronic conditions including but not limited to musculoskeletal diseases, cardiovascular disorders, skin diseases, inflammatory disorders, neuropsychiatric and metabolic disorders. Contraindications of cupping suggested by Nimrouzi, Mahbodi, Jaladat, Sadeghfard and Zarshenas (2014) include anemia, pregnancy, extreme cold weather, obesity or frail constitution, children less than 2 years of age or adults over 60 , before or after coitus. 


\subsubsection{Manual Therapy. Manual Therapy Includes Therapeutic Massage, Reflexology and Bone Setting}

\subsubsection{Therapeutic Massage}

Therapeutic massage, also known as dalk, is the manipulation of muscle and connective tissue using various techniques, to enhance organ function and body mechanics, promote relaxation and well-being thereby enabling the healing process. The mechanism of action is based on the evacuation or diversion of morbid humors and excess fluids from the body, thus maintaining homeostasis in the quality and quantity of four bodily humors responsible for the maintenance of health; black bile, yellow bile, phlegm and blood (Ahmed et al., 2014). Traditional Arab medicine identifies several varieties of therapeutic massage including strong pressure or friction (dalak e sulb), soft pressure or friction (dalak e layyin), moderate pressure or friction (dalak e moatadil), long duration (dalak kaseer), short duration (dalak e qaleel), rough (dalak e khashin); each achieving a certain effect in the body. For instance, soft pressure massage (dalak e layyin) is considered relaxing in nature, while moderate massage (dalak moatadil) improves and maintains blood circulation. Two additional types of massage incorporate using a cloth to facilitate application. The first type, rough (dalak e khashin) uses a rough textured cloth to improve blood circulation and facilitate nutritive energy to the muscles and organs. A second type, smooth (dalak e amlas), uses cloths like silk to improve peripheral blood circulation and provide nutrition to adjacent tissue.

Clinical applications. Jamal et al. (2013) reports general indications of massage including musculoskeletal and chronic pain, weight management, immune system support, reducing inflammation and ameliorating psychosomatic disorders. Therapeutic massage can be combined with aromatic oils and varies in its application based on temperament of organ and person, disease as well as condition of patient, season and desired outcome (Jafar, Ansari, Alam, Khalid, \& Mand, 2015). Rough massage has been identified as a treatment for alopecia, while smooth massage is indicated for conditions such as fatigue (Jamal et al., 2013). Though generally a safe procedure, Khalique and Siddiqui (2017) report contraindications for massage in inflammatory conditions, bleeding disorders, skin wounds and ulcers as well as severe osteoporosis, they also suggest that therapeutic massage should not be performed in any area of the body with a blood clot, fracture, open or healing wound and skin infections.

\subsubsection{Reflexology}

Egyptian hieroglyphics depict the ancient beginnings of reflexology (Cade, 2002). Evidence of reflexology is found on a wall painting in the tomb of Ankhmahor, illustrating a physician massaging the hands and feet of a patient (Callaway \& Burgess, 2009). Techniques used in the form of massage included thumb and finger pressure, as well as squeezing and pressing with the fingertips. Today such techniques may be referred to as reflexology (Embong, Soh, Ming, \& Wong, 2015). Reflexology, or Tadlik Alqadam, is based on the notion that there are reflex areas on the hands, feet and ear auricles that correspond to specific parts of the body (Oleson \& Flocco, 1993). Pressure applied to these specific areas assist in potentiating the normal functioning of the corresponding body part and thus can be used to restore and maintain the body's natural equilibrium and encourage healing (Asltoghiria \& Ghodsib, 2012).

Clinical applications. Khuda and Al-Shamrani (2018) report the integration of foot therapy in prescriptions for sub-acute or chronic strokes noted by Avicenna who recommended massaging the feet in warm salty water and hot oils. Referenced oils include lily flower, dill seed and chamomile flower (Zargaran, Zarshenas, Karimi, Yarmohammadi, \& Borhani-Haghighi, 2013). Other recommendations include support after a headache or migraine attack by applying several hours of foot massage with violet essential oil, salt, chamomile oil and clove gillyflower (Gorji \& Ghadiri, 2002). Foot therapy is recommended for the treatment of insomnia as well as anointing the forehead or feet (Feyzabadi, Javan, Mokaberinejad, \& Aliasl, 2014). To combat sexual dysfunction, massage to the soles of the foot with almond oil before sexual intercourse is recommended daily for a duration of five minutes (Molkara et al., 2018). Contraindications include foot infections or wounds, some circulatory and cardiac problems, recent surgery and high-risk pregnancies (Horowitz, 2004).

\subsubsection{Bone Setting}

The Ebers papyrus, one of the oldest and most comprehensive preserved medical documents in ancient Egypt, contains writings on bone setting (Serageldin, 2013). A notable surgeon of Arab medicine, Albucasis, compiled writings on cautery and bloodletting as well as bone setting (Anjum, 2013). Bone setting or Al Tajbeer, identifies procedures related to dislocated and fractured bones. In either of these forms of treatment, herbal remedies and dietary practices are utilized as an adjunct to treatment. In African countries, the role of bone setters in correcting fractures and dislocations is pivotal to many communities. Bone setting is a technique commonly recognized in Traditional Chinese Medicine for the treatment of fractured or dislocated bones by means of various manipulative therapies in conjunction with herbs (Robinson, 2006). While some value and prefer traditional bone setting to its 
western counter part, evidence indicates it has become less prominent in the Middle East as access to modern hospitals and private clinics is increasingly available (Ghazanfar, 2011).

Clinical applications. Manipulation techniques are intended to realign the musculoskeletal and ligamentous relationships. Use of this procedure is indicated for fractures or joint manipulation of limbs and lower jaw as well as spine, pelvis and shoulder, bed rest is recommended for the latter. Prescriptions noted include a mixture of egg yolk and certain local herbs molded into a plaster and applied to fractured, dislocated or displaced bones (Hurreiz, 2002). As demonstrated by Ghazanfar (2011), "once a bone fracture is corrected, a plaster is applied made from the resin of Acacia spp., seeds of tamarind or lentils mixed with egg. The fracture is then bound with cloth and the limb stabilized with wooden planks" (p. 3). Certain plants are also used in instances when the bone setter may have to break and reset the bone if it is not set properly. To aid recovery, a diet of date or bee honey is also prescribed. Other prescriptions include the preparation of poultice using black date and ground sheep fat to assist skeletal pain and dislocations (Asefzadeh \& Sameefar, 2001). To aid swollen joints, preparations of boiled mellow leaf mixed with egg yolk and salt are used. Complications of bone setting include mal-union and non-union of fractures, compartment syndrome, tetanus, deformities, chronic osteomyelitis and soft tissue infections, gangrene and amputation (Manjunath, 2016). Contraindications of bone setting are comparable to those of other manual therapies including but not limited to inflammatory processes and severe forms of osteoporosis.

\subsubsection{Auricular Therapy}

Auricular therapy is a treatment modality in which specific points are stimulated on the ear with the goal of correcting the body's dysfunction (Round, Litscher, \& Bahr, 2013). A postulated relationship between external body points and various effects on the body, is a part of the medical historical record of a number of ancient societies. In the $16^{\text {th }}$ and $18^{\text {th }}$ centuries, rudimentary knowledge of ear acupuncture and auricular therapy was found in Arab folk medicine (Landgren, 2008). Medieval Arabic medicine also describes a correlation between internal organs and at least one external point on the body (Ramey, 2000). The practice of cauterizing a part of the ear with a hot metal probe has been reported among certain tribes in Arabia, "likely a vestige of the acupuncture practiced in ancient Egypt and Saudi Arabia" (Gori \& Firenzuoli, 2007). The Ebers papyrus of 1550 B.C. describes a system of channels and vessels in the body; which closely resembles the Chinese system of meridians (Gori \& Firenzuoli, 2007).

Clinical applications. Hippocrates described the method of auricular therapy for the treatment of impotence and observed that women were less likely to conceive if points on the ear were stimulated (Gori \& Firenzuoli, 2007). Egyptologist Alexandre Varille, documented that women in ancient Egypt had their external ear cauterized with heat or pricked with a needle as a form of contraception. Clinical and basic research suggests auriculotherapy can be effective in the treatment of pain, and for anxiety related disorders (Gori \& Firenzuoli, 2007). Gori and Firenzuoli (2007) report the cauterization of the external ear for treatments of sciatic pain and sexual dysfunction. Contraindications for auricular therapy include pregnancy, those who are immune compromised and in severe bleeding disorders (Tan, Molassiotis, Wang, \& Suen, 2014).

\subsubsection{Fomentation}

Fomentation, or Takmeed, has been used by many ancient medical traditions (Sinclaire, 2007). Fomentation is the soothing application of warm substances to the body, expediting the delivery of heat or moisture to the body for purposes of healing. A poultice or compress is often used, and when herbs are necessary, they are applied to the skin through a cloth soaked in an infusion or decoction of herbs. Traditionally, wool and cotton material are commonly used for their ability to retain heat and moisture well. There are several types of fomentation, including hot, dry, wet, cold, herbal and whole body fomentation (Hamid, 2018). For instance, hot fomentation is whereby a towel is dipped in hot water or a towel is made hot by steam application, whereas wet fomentation relies on the use of a towel dipped in water boiled with analgesic or anti-inflammatory herbs (Hamid, 2018). Application of fomentation varies according to the areas of the body being treated.

Clinical applications. Fomentation enhances circulation, thereby increasing elimination of wastes and toxins from the body and relieving internal congestion. Indications of fomentation include local swelling and pain, sinusitis, bloating, nervous tension, sleeplessness, menstrual pain, colic, constipation, cough, congestion, as analgesic, and muscle relaxant. Hot dry fomentation is beneficial for flatulence whereas hot moist fomentation is beneficial for arthritis (Baig, Quamri, Khan, AnzarAlam, Maaz, \& Ahmed, 2014).

Bitschai (1952) provides examples of prescriptions for the use of pomegranate flowers, celery and coriander. Manik, Wahid, Islam, Pal and Ahmed (2013) provide indications for fomentation of warmed wheat bran, salt and/or dill leaves applied to the stomach for the treatment of bloating (Larijani et al., 2016). Tumpa, Hossain and 
Ishika (2014) indicate the use of boiled leaves of Indian ash tree applied as a fomentation for the treatment of local swelling and pain (Manik et al., 2013). Sultana, Lamatunoor, Begum and Qhuddsia (2017) indicate use of the root of velvet bean boiled in water, and a sterile cloth soaked in the warm solution and applied for conditions related to pain in the vagina or enlargement of vaginal tissue due to parturition (Tumpa, Hossain, \& Ishika, 2014). Unani scholars have prescribed hot fomentation with warm water or with decoction of various herbs such as common wormwood, orris root or leaves of cherry to relieve uterine pain (Sultana et al., 2017). Contraindications include loss of sensation caused by spinal cord injury, diabetic neuropathy, rash or other skin conditions that could be made worse by heat, inflammation, swelling, open wounds including burn, sore or cracked skin from eczema or severe chapping and malignancy (Sinclaire, 2007).

2.2.8 Hydrotherapy. Hydrotherapy Includes the Medicinal Bath or Hammām, Sitz bath, Hand \& Foot Bath, Vaporization, Steam \& Aromatherapy

The use of water for therapeutic purposes is found amongst many traditions. The Rig Veda, a religious text of ancient India, as well as prescriptions found in biblical records, describe hydrotherapy treatments used for healing (Wardle, 2013). Use of 'gush of water' is mentioned in medical treatise based on writings of Hippocrates, Galen, Celsus as well as Avicenna and Rhazes. The pouring of water, alone or in combination with other prescriptions, was applicable in a variety of illnesses such as fever, joint pain, psychic disease and headache but also considered a general therapeutic method (Jacoby, 2002). Hippocrates described hydrotherapy in his writings noting that "for the bath soothes the pain in the side, chest and back; cuts the sputum, promotes expectoration, improves the respiration, and allays lassitude: for it soothes the joints and outer skin, and is diuretic, removes the heaviness of the head, and moistens the nose" (p.12) (Wardle, 2013). Furthermore, along with lifestyle modifications, Hippocrates viewed the application of water for healing as an essential component of his regimen (Wardle, 2013).

\subsubsection{1 Ḥammām}

Hammam, or traditional bath house, was an essential fabric of Islamic society. Following the rise of Islam, rapid development in the architecture of hammām was observed (Sibley \& Jackson, 2012). Centrally located near mosques, souks and residential areas, a hammām provided a venue for the completion of ablutions necessary before praying but also served as a platform for social interaction and rituals (Sibley, 2008). A traditional hammam consists of three consecutive rooms with one room leading to the other furnishing specific provisions and conditions; the cold (frigidarium), the warm (tepidarium), and the hot (calidarium) (Raftani \& Radoine, 2008). Avicenna compared each chamber to a season; the bather passing through each chamber within a specified duration of time, so he is amenable and adaptable to the changes of every season (Sherwani, Ahmed, Naaz, Khan Sherwani, \& Khan, 2006). The hammam ritual did not involve a massage, however it began to be performed later on (Özköse, 2005). Kolb and Dumreicher (2008) completed a case study of hammām traditions in five different countries around the Mediterranean, and concluded that a vivid social life, specific washing ceremonies and festive rituals continue to be practiced.

Clinical applications. Several types of baths have been described, including medicinal bath, sea bath, thermal bath and oil bath to name a few (Nasir et al., 2018). Avicenna describes the positive effects of the hammām, particularly observing the effect of bathing on promoting circulation, reducing viscosity of the humors, enhancing metabolism and overall health, aiding detoxification, regulating weight and strengthening vitality. He also appreciated the bath for its powerful, purifying and cleansing effect both in a physical and spiritual sense. According to Al-Ghazali, a prominent philosopher and mystic (11th century), a bath facilitates opening of the pores, extraction of superfluous humors, dissolves flatulence and enables urine flow (De Bustinza, 2016). Use of a hammām is contraindicated on an empty stomach, during pregnancy, fever and asthenia and should not be recommended for prolonged stay (Hamid, 2018).

\subsubsection{Sitz Bath}

A sitz bath, or Abzan, is an immersion bath in which an individual will sit in a tub with water covering the hips, buttocks and lower abdomen (Wardle, 2013). This regimen activates the organs of the abdomen and pelvis by increasing circulation and thereby reducing muscle congestion and inflammation (Baig et al., 2014; Nayab, 2016). Evidence exists that Avicenna indicated the use of sitz bath in various diseases, and also used the bath as a means to deliver local application of herbal medicines (Madinah, 2009). There are four types of a sitz bath; hot, cold, neutral and alternating between hot and cold (Hamid, 2018).

Clinical applications. Examples of herbs used in conjunction with the bath include olive oil, yarrow and milk (Baig et al., 2014; Nayab, 2016). Other decoctions used in a sitz bath include preparations of chamomile, yellow sweet clover, celery, leaves of common marshmallow and maidenhair fern (Hussain, Ahmed, Jahan, \& Abida, 
2016). Prescriptions for the treatment of dysmenorrhea include the use of common juniper, rue, chamomile, sweet marjoram, wild mint and celery (Sultana et al., 2017). Rhazes, a Persian physician, philosopher and alchemist, advised using a sitz bath with a solution using the skin of pomegranate to treat anal pain (Al-Humadi \& Al-Samarrai, 2009). A sitz bath with warm water and flax was also indicated for the treatment of psoriasis (M. S. Khan, Lari, \& Khan, 2018). Sitz baths are contraindicated in open wounds or active bleeding including vaginal bleeding, prolapsed organs, acute inflammation, painful conditions with spasm or colic, pregnancy and cardiovascular concerns (Wardle, 2013).

\subsubsection{Hand \& Foot Bath}

During hand and foot bath therapy, a small tub containing water is utilized, hands or feet are placed into the tub ensuring water covers the forearms or calf muscle. Rhazes prescribed foot baths, or Hammam Alqadam, for the treatment of gout and observed that the temperature of water and the time of application were essential factors involved in gout management (Changizi Ashtiyani, Golestanpour, Shamsi, Tabatabaei, \& Ramazani, 2012). An underlying mechanism responsible for the efficacy of foot baths is due to reducing the sympathetic nervous system and affecting autonomic nervous activity (Yamamoto, Aso, Nagata, Kasugai, \& Maeda, 2008).

Clinical applications. Saeki, Y, N Nagai and M Hishinuma (2007) have demonstrated significant effects of hand and foot baths in relieving stress, combating fatigue and insomnia symptoms in addition to increasing overall body temperature and white blood cell activity, yielding immune boosting effects and increasing general health and well-being (Saeki, Nagai \& Hishinuma, 2007). Oils, herbal extracts or decoctions are used in conjunction with the bath. Prescriptions can be found for using mustard and warm water for the treatment of dysmenorrhea (Rehman, Begum, Anjum, \& Tabasum, 2013). For the treatment of dry feet, a warm foot bath is recommended followed by rubbing the feet with oil or fat including the fat of goat and cattle as well as castor, olive and sesame oil (Jedkareh, Esmaeili, Alembagheri, \& Mortazavi, 2016). Contraindications for a warm hand or foot bath include skin rash and open wounds, however if a bath is prepared hot then contraindications would include loss of sensation in hands or feet, diabetes and lymphedema of upper or lower extremities (Sinclaire, 2007).

\subsubsection{Vaporization, Steam \& Aromatherapy.}

Inhalation therapy was developed during the Islamic ages, Muslim doctors employed it as part of their treatments due to ease of preparation and use (Khashan, 2018). Avicenna introduced the process of extracting essential oils by means of steam distillation (Saffari \& Pakpour, 2012). Albucasis believed aromatherapy was greatly beneficial and developed the medicine of aromatherapy and its applications (Alraghran \& Khatib, 2016). Steam \& vaporization therapy, or Bukhoor, involves the inhalation of water vapor from a bowl of boiling water, with the back of the head covered with a towel to prevent evaporation. This method of treatment is generally applied for 5-10 minutes, and an essential oil, menthol or incense may be added to the boiling water (Saad \& Said, 2011). This method is still routinely applied in the Arab and Islamic world.

Clinical applications. Vaporization is indicated for colds, headaches, acne, cough and as an air freshener. Common oils used during vaporization include amber, chamomile, saffron, sandalwood, violet, camphor, mustard, and musk. Traditional prescriptions of inhalation include raw amber dissolved in chamomile or quince oil, mixed with a small amount of saffron to treat conjunctivitis. Equal parts of sweet almond oil, viola oil, and women's milk dissolved in a small amount of saffron are used to treat weakness of the optic nerve (Khashan, 2018). These preparations are placed on the hand and patients are advised to inhale the mixture. An alternate preparation for vaporization includes immersing a thin piece of wet cloth in a preparation of sandalwood and musk dissolved in rose water, patients are advised to vaporize it by the rods of cardamom (Jalkhi \& Kakhshan, 2015). Lavender was known to Unani physicians and was recognized for its beneficial treatment of melancholy, mania, epilepsy, amnesia, anxiety, and numbness as it is efficacious for removing morbid matters from the brain and clarifying intellect as well as providing strength to other organs including the liver, spleen, stomach and intestines (Khan et al., 2015). Preparation of the leaves of chrysanthemum are used in a steam bath for its sedative and antispasmodic effects, often used to relieve muscle aches, nervousness, and contractions of the uterus (Abu-Rabia, 2012). Steam inhalation is contraindicated for inflammatory skin conditions, and injuries to the respiratory tract including burns have been reported as an adverse effect of application (Balakrishnan, Tijunelis, Gordon, \& Prasad, 1996).

\subsubsection{Physical Movement. Physical Movement Comprises Exercise and Ritual Prayer}

\subsubsection{Exercise}

Noted as an important component of ancient medical theory, physicians emphasized the centrality of exercise and diet as key components of one's way of life (Berryman, 2012). Along with food and sleep, Avicenna indicated exercise, or riyazat, as the third principle in the preservation of good health (Bakhtiar, Gruner, Shah, \& Crook, 
2014). He proposed that exercise has a protective effect on health by preventing temperament and humoral disorders, a notion supported by Hippocrates and Galen (Cetkin, Bahsi, \& Orhan, 2016). In addition to the proper duration of exercise and the best time to commence physical activity, Avicenna expressed that there is an exercise type for each person, and for various parts of the body. Additional principles of exercise include age and temperament of a person, present environment and condition of the body (Firdaus \& Sultana). For instance, with vociferation from high-pitched and deep voice, chest and respiratory organs can be made to exercise. The notion of healing sounds is a similar practice to the six healing sounds found in Qigong (Liu, Schaffer, Herrs, Chollet, \& Taylor, 2015).

Clinical applications. To maintain health and a strong physical constitution, the body requires exercise as well as rest. Arab and Muslim physicians prescribed moderate exercise to strengthen the organs, increase the vital force of the body, eliminate waste products and increase appetite (Saad \& Said, 2011). Islamic medieval texts reveal doctors paid close attention to the patient's regimen; especially exercise, a restful environment, and sleep and believed these factors in addition to the patients' temperament, age, and present environment should be adjusted as needed, to ensure the patient's daily life is conducive to recovery (Dols, 1987). Exercise is contraindicated on either a full or empty stomach as well as in the presence of excess temperaments in the body, namely hot, dry or cold (Firdaus \& Sultana).

\subsubsection{Ritual Prayer}

Islamic ritual prayer, or salat, consists of a set of physical postures, or intentional movements including standing, bowing, prostrating and sitting, performed a minimum of five times per day (Doufesh, Ibrahim, \& Safari, 2016). Considered to be a mild to moderate form of physical activity, salat provides psychological, musculoskeletal and neurophysiological effects (Ibrahim, Sian, Shanggar, \& Razack, 2013). This ritual prayer can be compared to tai chi and yoga as it involves the movement of the whole body as well as providing those practicing a meditative platform (Doufesh et al., 2016). It has been observed, that during this ritual prayer most of the joints and muscles of the body are engaged with little effort, potentially playing an integral role not only in cerebral blood flow but also postural reflexes (Reza, Urakami, \& Mano, 2002).

Clinical applications. Considered a type of meditation, prayer may convey many of the psychological and biological benefits associated with improved health including reduction in blood pressure and heart rate, altering levels of serotonin and melatonin, boosting the immune response, reducing stress and promoting positive mood states including reduction of anxiety, pain, and enhancing self-esteem as well as promoting a favorable influence on overall quality of life (Andrade \& Radhakrishnan, 2009). Spiritual meditation has been found to impart a stronger effect on anxiety, spiritual experiences, and tolerance to pain when compared to secular meditation. Islamic ritual prayer as well as voluntary and congregational prayers, unique in their form and spirit, are believed to embody spiritual, psychological, physical and moral benefits (Syed, 2003). Many employ this simple, sacred and spiritual lifestyle to enhance health, happiness and longevity of the individual and community. There are no contraindications for the performance of salat.

\section{Discussion}

Applied therapy has long played a significant role in providing health promotive, preventive and curative care. Based on this research, we have demonstrated a clear and concise definition as well as a logical and systematic categorization of the applied therapy element. This work provides a definition of applied therapy along with its components, and typology of primary and supportive methods, as a fundamental step in continuing the evolution of the TAIM conceptual model and advancing our understanding of the diverse practices under the rubric of applied therapy.

While creating a typology is an integral step in providing a hierarchal categorization, it presents several limitations. First, in theory, it is possible that a method can be both primary and supportive. For instance, if two primary therapies are applied in consecutive order to systematically address an imbalance, one could stipulate that the second method albeit still primary by definition, acts as supportive. Second, if a primary method utilized induces a state whereby the resulting effect is similar to a supportive method then it becomes difficult to delineate whether the efficacy is attributed to the initial or combined effect. This can be illustrated in the following example whereby a primary method such as hydrotherapy induces diaphoresis, a supportive method. In either case of the proposed limitations, our typology becomes relevant as we convey an interconnectivity among the methods and therefore a space where a synergistic relationship is possible. Lastly, while we attempt to highlight the most commonly utilized methods in accordance with modern use, historical account and Avicenna's compendium of regimental therapies, there may be additional and less obvious methods requiring further study. 
This typology opens a plethora of research opportunities about applied therapies. What are clinical patterns of utilization, and how do they vary geographically? What are socioeconomic factors associated with use? How does a user's cultural and religious view impact acceptability of the different types of therapy? To what extent do practitioners use the different types of applied therapy, and are the different types of therapy used together? Are there instances where practitioners avoid using a combination of therapeutic approaches? In what ways are authentic prescriptions being preserved and disseminated? How are the varied therapies integrated into medical care?

\section{Conclusion}

By delving comprehensively into the components of the TAIM conceptual model, we have set out to define \& categorize the applied therapy element, to present the proposed therapies in a cohesive and schematic context and to suggest a hierarchical presentation of the methods utilized. While health practitioners and patients continue to apply these methods as they endeavor to improve their health care coverage, a deeper understanding of traditional and indigenous health practices must be an evolving process. Researchers can begin to use this comprehensive TAIM taxonomy to continue examining the respective elements, and systematically explore the theoretical and therapeutic applications.

\section{Acknowledgements}

The authors declare that they have no competing interests and received no specific funding for this work. Sara AlRawi conceived of the study, participated in analyses, drafted and final edited the manuscript. Michael Fetters participated in the design and coordination, assisted with analysis and helped to draft and finalize the manuscript. All authors read, reviewed, and approved the final manuscript. A special thank you to Rania Ajilat for her assistance with manuscript preparation.

\section{Competing Interests Statement}

The authors declare that there are no competing or potential conflicts of interest.

\section{References}

Abdualkader, A. M., Ghawi, A. M., Alaama, M., Awang, M., \& Merzouk, A. (2013). Leech therapeutic applications. Indian Journal of Pharmaceutical Sciences, 75(2), 127-137. Retrieved from https://www.ncbi.nlm.nih.gov/pmc/articles/PMC3757849/

Abu-Rabia, A. (2012). Ethno-botanic treatments for paralysis (falij) in the Middle East. Chinese Medicine, 3(04), 157. http://dx.doi.org/10.4236/cm.2012.34025

Ahmad, T., \& Anwar, M. (2009). Clinical importance of leech therapy. Indian Journal of Traditional Knowledge, $8(3), \quad 443-445 . \quad$ Retrieved from http://nopr.niscair.res.in/bitstream/123456789/5069/1/IJTK\%208\%283\%29\%20443-445.pdf

Ahmed, K., Jahan, N., Aslam, M., Kausar, H., Khalid, M., \& Ali, H. (2014). Dalak (Massage) in unani medicine: A review. International Journal of Advanced Ayuverda, Yoga, Unani, Siddha and Homeopathy, 3(1), 162-174. Retrieved from http://medical.cloud-journals.com/index.php/IJAAYUSH/article/view/Med-118

Ahmedi, M., \& Siddiqui, M. R. (2014). The value of wet cupping as a therapy in modern medicine-an Islamic perspective. Webmed Central Alternative Medicine, 5(12), 1-14. http://dx.doi.org/10.9754/journal.wmc.2014.004785

Al-Humadi, A., \& Al-Samarrai, S. (2009). Treatment of anorectal diseases by al-Rāzī. Journal of the Islamic Medical Association of North America, 41, 122-133. https://doi.org/10.5915/41-3-5116

Alraghran, A., \& Khatib, C. (2016). The new information about aromatherapy and scents. International Society for the History of Islamic Medicine, 64-83.

Alrawi, S. N., \& Fetters, M. D. (2012). Traditional arabic \& islamic medicine: a conceptual model for clinicians and researchers. Global Journal of Health Science, 4(3), 164-169. https://doi.org/10.5539/gjhs.v4n3p164

Alsanad, S. M., Asim, A. A. H., Gazzaffi, I. M. A., \& Qureshi, N. A. (2018). History of cautery: The impact of ancient cultures. Journal of Advances in Medicine and Medical Research, 25(9), 1-17. https://doi.org/10.9734/JAMMR/2018/40370

Andrade, C., \& Radhakrishnan, R. (2009). Prayer and healing: A medical and scientific perspective on randomized controlled trials. Indian Journal of Psychiatry, 51(4), 247-253. https://doi.org/10.4103/0019-5545.58288

Anjum, S. (2013). Al-Zahrawi: A prominent Muslim medical scientist and his impact on west. Revelation and 
$\begin{array}{lccc}\text { Science, } & 3(2), & 51-56 . & \text { Retrieved } \\ \text { https://pdfs.semanticscholar.org/bf58/9f5735ab090256eeb19bdb80df6b462157b9.pdf }\end{array}$

Asefzadeh, S., \& Sameefar, F. (2001). Traditional healers in the Qazvin region of the Islamic Republic of Iran: A qualitative study. Eastern Mediterranean Health Journal, 7(3), 544-550. Retrieved from http://applications.emro.who.int/emhj/0703/emhj_2001_7_3_544_550.pdf

Asltoghiria, M., \& Ghodsib, Z. (2012). The effects of Reflexology on sleep disorder in menopausal women. Procedia - Social and Behavioral Sciences, 31, 242-246. https://doi.org/10.1016/j.sbspro.2011.12.049

Baig, M. G., Quamri, M. A., Khan, M. S., AnzarAlam, M., Naaz, F., \& Ahmed, N. Z. (2014). Pain alleviation in Unani medicine - A conceptual analysis. International Journal of Pharmaceutical Sciences and Research, 5(12), 927-934. Retrieved from http://www.ijpsr.info/docs/IJPSR14-05-12-003.pdf

Bakhtiar, L., Gruner, O. C., Shah, M. H., \& Crook, J. R. (2014). The canon of medicine (al-Qānūn fì'l-tibb). Chicago, IL: KAZI Publications.

Balakrishnan, C., Tijunelis, A. D., Gordon, D. M., \& Prasad, J. K. (1996). Burns and inhalation injury caused by steam. Burns, 22(4), 313-315. https://doi.org/10.1016/0305-4179(95)00137-9

Bergum, N., \& Ansari, A. A. (2012). Venesection (Fasd). Hamdard Medicus, 55(1), 97-103. Retrieved from http://applications.emro.who.int/imemrf/Hamdard_Med/Hamdard_Med_2012_55_1_97_103.pdf

Berryman, J. (2012). The art of medicine: motion and rest: Galen on exercise and health. The Lancet, 380(9838), 210-211. https://doi.org/10.1016/S0140-6736(12)61205-7

Bitschai, J. (1952). The history of urology in Egypt. American Journal of Surgery, 83(2), 215-224. https://doi.org/10.1016/0002-9610(52)90214-6

Cade, M. (2002). Reflexology. The Kansas Nurse, 77(5), 5-6. Retrieved from https://www.ncbi.nlm.nih.gov/pubmed/12078350

Callaway, K., \& Burgess, S. (2009). A history of massage in Lisa Casanelia and David Stelfox (3rd ed.). Foundations of Massage. Churchill Livingston. ISBN: 9780729578691.

Cetkin, M., Bahsi, I., \& Orhan, M. (2016). Evaluation of exercise in canon of medicine. Archives of Iranian Medicine, 19(10), 743-746. https://doi.org/0161910/AIM.0014

Changizi Ashtiyani, S., Golestanpour, A., Shamsi, M., Tabatabaei, S. M., \& Ramazani, M. (2012). Rhazes' prescriptions in treatment of gout. Iranian Red Crescent Medical Journal, 14(2), 108-112. Retrieved from https://www.ncbi.nlm.nih.gov/pmc/articles/PMC3372038/

De Bustinza, V. (2016). How early Islamic science advanced medicine. National Geographic History. Retrieved from https://www.nationalgeographic.com/archaeology-and-history/magazine/2016/11-12/muslimmedicine-scientific-discovery-islam/

Deuraseh, N. (2006). The Islamic tradition based on the book of medicine (Kitab Al-Tibb) Of Sahih Al-Bukhari. Journal of the International Society for the History of Islamic Medicine, 5, 2-14. Retrieved from https://www.ishim.net/ishimj/910/JISHIM\%20NO.9\%20PDF/01.pdf

Dols, M. W. (1987). Insanity and its treatment in Islamic society. Medical History, 31, 1-14. https://doi.org/10.1017/S0025727300046287

Doufesh, H., Ibrahim, F., \& Safari, M. (2016). Effects of Muslims praying (Salat) on EEG gamma activity. Complementary Therapies in Clinical Practice, 24, 6-10. https://doi.org/10.1016/j.ctcp.2016.04.004

El-Wakil, A. (2011). Observations of the popularity and religious significance of blood-cupping (al-hijama) as an Islamic medicine. Contemporary Islamic Studies. https://doi.org/10.5339/cis.2011.2

Embong, N. H., Soh, Y. C., Ming, L. C., \& Wong, T. W. (2015). Revisiting reflexology: Concept, evidence, current practice, and practitioner training. Journal of Traditional and Complementary Medicine, 5(4), 197-206. https://doi.org/10.1016/j.jtcme.2015.08.008

Faiz, A., \& Ali, F. (2018). Applied part of Kulliyat with reference to Venesection (Fasd): A review. International Journal of Research and Analytical Reviews, 5(3), 583y-586y. Retrieved from https://ijrar.com/upload_issue/ijrar_issue_1701.pdf

Farid, M., \& El-Mansoury, A. (2015). Kaiy (traditional cautery) in Benghazi, Libya: Complications versus effectiveness. Pan African Medical Journal, 22, 98. http://dx.doi.org/10.11604/pamj.2015.22.98.6399 
Feyzabadi, Z., Javan, R., Mokaberinejad, R., \& Aliasl, J. (2014). Comparing insomnia treatment in Iranian traditional medicine and modern medicine. History of Medicine Journal, 6(19). Retrieved from http://journals.sbmu.ac.ir/en-mh/article/view/14878/0

Firdaus, S., \& Sultana, N. (2018). Regimental therapy a drugless regimen for well being of a person in USM and its important place in the mainstream treatment of USM. Journal of Complementary and Alternative Healthcare, 8(1), 1-11. https://doi.org/10.19080/JCMAH.2018.08.555727

Ghazanfar, S. A. (2011). Medicinal and aromatic plants Arabia and Iran. Ethnopharmacology: Encyclopedia of Life Support Systems (EOLSS), 2, 1-8. Retrieved from http://fliphtml5.com/vvyc/mpjk/basic

Gori, L., \& Firenzuoli, F. (2007). Ear acupuncture in European traditional medicine. Evid Based Complement Alternat Med, 4(Suppl 1), 13-16. https://doi.org/10.1093/ecam/nem106

Gorji, A., \& Ghadiri, M. K. (2002). History of headache in medieval Persian medicine. The Lancet: Neurology, l(8), 510-515. https://doi.org/10.1016/S1474-4422(02)00226-0

Greenstone, G. (2010). The history of bloodletting. British Columbia Medical Journal, 52(1), 12-14. Retrieved from https://www.bcmj.org/premise/history-bloodletting

Hamid, A. (2018). Ilaj-bil-tadbeer (regimental therapy): A noble method of treatment in Unani medicine: A review. International Journal of Medicine Research, 3(3), 01-06. Retrieved from http://www.medicinesjournal.com/archives/2018/vol3/issue3/3-2-38

Horowitz, S. (2004). Evidence-based reflexology: A pathway to health. Alternative \& Complementary Therapies, 211-216. https://doi.org/10.1089/1076280041580378

Hurreiz, S. H. (2002). Folklore and Folk life in the United Arab Emirates. London: RoutledgeCurson. https://doi.org/10.4324/9781315028682

Hussain, M. T., Ahmed, G., Jahan, N., \& Abida, M. (2016). Pathophysiology and Treatment or Urolithiasis in Unani Medicine. Indian Journal of History of Science, 51(2), 217-226. https://doi.org/10.16943/ijhs/2016/v51i2/48433

Ibrahim, F., Sian, T. C., Shanggar, K., \& Razack, A. H. (2013). Muslim prayer movements as an alternative therapy in the treatment of erectile dysfunction: A preliminary study. Journal of Physical Therapy Science, 25(9), 1087-1091. https://doi.org/10.1589/jpts.25.1087

Jacoby, J. (2002). Pouring water over the body--hydrotherapy prescriptions in the late Middle Ages. Sudhoffs Arch, 86(1), 54-68. Retrieved from https://www.ncbi.nlm.nih.gov/pubmed/12168234

Jafar, M., Ansari, A. N., Alam, M. I., Khalid, M., \& Mand, D. (2015). Dalk (Massage): A unani therapeutic manipulative procedure in rehabilitation of psychosomatic and neurological disorders. International Journal of Hospitality Management, 3(3), 36-38. Retrieved from https://www.cabdirect.org/cabdirect/FullTextPDF/2015/20153371363.pdf

Jalkhi, B., \& Kakhshan, A. (2015). Inhalation therapy in kitab al-Umdah al-kuhliyah fi al-Amrad al-Basariyah. International Society for the History of Islamic Medicine, 48-51. Retrieved from https://www.researchgate.net/publication/324068708_Inhalation_Therapy_In_Kitab_al-'Umdah_al-kuhliyah _fi_al-amrad_al-basariyah

Jamal, A., Siddiqui, A., Sadiq, S. U., \& Jamil, S. S. (2013). Therapeutic significance of dalak (massage) in the management of musculoskeletal disarray. Hamdard Medicus, 56(4), 86-91. Retrieved from http://applications.emro.who.int/imemrf/Hamdard_Med/Hamdard_Med_2014_56_4_86_91.pdf

Jedkareh, A., Esmaeili, S., Alembagheri, A., \& Mortazavi, S. A. (2016). Comparing the etiology and treatment of skin fissure in traditional and conventional medicine; a brief review. Research Journal of Pharmacognosy, 3(1), 49-54. Retrieved from http://www.rjpharmacognosy.ir/article_12104_20b54cae6c691c4f030518139b39a7f7.pdf

Jha, K., Garg, A., Narang, R., \& Das, S. (2015). Hirudotherapy in medicine and dentistry. Journal of Clinical and Diagnostic Research, 9(12), ZE05-07. https://doi.org/10.7860/JCDR/2015/16670.6918

Khalique, A., \& Siddiqui, M. (2017). Historical background and medical significance of dalk (massage): A review. International Journal of Unani and Integrative Medicine, 1(2), 15-20. Retrieved from http://www.unanijournal.com/articles/13/1-1-13-782.pdf

Khan, J. A., Siddiqui, M. A., Itrat, M., \& Jamal, M. A. (2014). A review on therapeutic application of fasd 
(venesection) in unani medicine. Journal of Biological \& Scientific Opinion, 2(1), 101-102. https://doi.org/10.1016/S0254-6272(18)30639-3

Khan, M. A., Raza, F., \& Khan, I. A. (2015). Ibn Sina and the roots of the seven doctrines of preservation of health. Acta Medico-Historica Adriatica, 13(Suppl 2), 87-102. Retrieved from https://pdfs.semanticscholar.org/4b27/7a5e0fb8d0a616724b592cf3ae8488d0f677.pdf?_ga=2.153040446.60 $7883443.1565273538-510541118.1565273538$

Khan, M. S., Lari, Q. H., \& Khan, M. A. (2018). Therapeutic approach of unani medicine in the management of psoriasis (DA-US-SADAF). European Journal of Pharmaceutical and Medical Research, 5(2), 200-205. Retrieved from https://www.ejpmr.com/admin/assets/article_issue/1517395147.pdf

Khuda, I., \& Al-Shamrani, F. (2018). Stroke medicine in antiquity: The Greek and Muslim contribution. Journal of Family and Community Medicine, 25(3), 143-147. https://doi.org/10.4103/jfcm.JFCM_8_17

Kolb, B., \& Dumreicher, H. (2008). The hammam - A living cultural heritage. ArchNet-International Journal of Architectural Research, 2(3), 17-28. https://dx.doi.org/10.26687/archnet-ijar.v2i3.278

Landgren, K. (2008). Ear Acupuncture: A Practical Guide. Churchill Livingston: Elsevier. ISBN: 9780702033179

Larijani, B., Esfahani, M. M., Moghimi, M., Shams Ardakani, M. R., Keshavarz, M., Kordafshari, G., Nazem, E., et al. (2016). Prevention and treatment of flatulence from a traditional Persian medicine perspective. Iran Red Crescent Medical Journal, 18(4), e23664. https://doi.org/10.5812/ircmj.23664

Liu, W., Schaffer, L., Herrs, N., Chollet, C., \& Taylor, S. (2015). Improved sleep after Qigong exercise in breast cancer survivors: A pilot study. Asia-Pacific Journal of Oncology Nursing, 2(4), 232-239. https://doi.org/10.4103/2347-5625.170537

Lone, A. H., Ahmad, T., Anwar, M., Habib, S., Sofi, G., \& Imam, H. (2011). Leech therapy- a holistic approach of treatment in unani (greeko-arab) medicine. Ancient Science of Life, 31(1), 31-35. Retrieved from http://www.ancientscienceoflife.org/article. $a s p ?$ issn $=0257-7941 ;$ year $=2011 ;$ volume $=31$; issue $=1 ;$ spage $=31$;e page $=36$; aulast $=$ Lone

Lone, A. H., Ahmad, T., Anwar, M., Sofi, G., Imam, H., \& Habib, S. (2012). Perception of health promotion in Unani herbal medicine. Journal of Herbal Medicine, 2(1), 1-5. https://doi.org/10.1016/j.hermed.2012.02.003

Madinah, S. (2009). Avicenna's canon of medicine and modern urology part III: Other bladder diseases. Urology Journal, 6(1), 138-144. Retrieved from http://journals.sbmu.ac.ir/urolj/index.php/uj/article/view/93/92

Manik, M. K., Wahid, M. A., Islam, S. M. A., Pal, A., \& Ahmed, K. T. (2013). A comparative study of the antioxidant, antimicrobial and throbolytic activity of the bark and leaves of lannea coromandelica (anacardiaceae). International Journal of Pharmaceutical Sciences and Research, 4(7), 2609-2614. https://doi.org/10.13040/IJPSR.0975-8232.4(7).2609-14

Manjunath, V. (2016). Patronizing traditional bone setters and its complications- A study in Bangalore. Journal of Dental and Medical Services, 16(6:1), 125-130. Retrieved from http://iosrjournals.org/iosr-jdms/papers/Vol15-Issue\%206/Version-1/Y150601125130.pdf

Mehta, P., \& Dhapte, V. (2015). Cupping therapy: A prudent remedy for a plethora of medical ailments. Journal of Traditional and Complementary Medicine, 5(3), 127-134. https://doi.org/10.1016/j.jtcme.2014.11.036

Mohammad, S. H., Fasihuzzaman, \& Jabeen, A. (2015). Hijamah (cupping therapy): A noble method of treatment in unani medicine. International Journal of Research in Ayurveda and Pharmacy, 6(2), 207-214. https://doi.org/10.7897/2277-4343.06243

Molkara, T., Akhlaghi, F., Ramezani, M. A., Salari, R., Vakili, V., Kamalinejad, M., Bordbar, M. R. F., ... Motavasselian, M. (2018). Effects of a food product (based on Daucus carota) and education based on traditional Persian medicine on female sexual dysfunction: A randomized clinical trial. Electronic Physician Journal, 10(4), 6577-6587. https://doi.org/10.19082/6577

Nasir, A., Fatma, G., Ali, W., \& Ahmad, M. A. (2018). Role of Ilaj-bil-tadbeer (regimental therapy) as non-medical therapy in unani system of medicine. European Journal of Pharmaceutical and Medical Research, 5(2), 213-218. Retrieved from https://www.ejpmr.com/admin/assets/article_issue/1517395296.pdf

Nayab, M. (2016). Ābzan (Sitz bath)-An effective mode of treatment in "Ilāj bit Tadbīr (regimental therapy). The Pharma Innovation, 5(12, Part A), 45. Retrieved from http://www.thepharmajournal.com/archives/2016/vol5issue12/PartA/6-3-23-259.pdf 
Nikhat, S., \& Fazil, M. (2013). Kayi (Cauterization): A tribute to unani scholars. Medical Journal of Islamic World Academy of Sciences, 21(2), 81-88. https://doi.org/10.12816/0001494

Nimrouzi, M., Mahbodi, A., Jaladat, A. M., Sadeghfard, A., \& Zarshenas, M. M. (2014). Hijamat in traditional Persian medicine: Risks and benefits. Journal of Evidence-Based Complementary Alternative Medicine, 19(2), 128-136. https://doi.org/10.1177/2156587214524578

Oleson, T., \& Flocco, W. (1993). Randomized controlled study of premenstrual symptoms treated with ear, hand, and foot reflexology. Obstetrics \& Gynecology, 82(6), 906-911. Retrieved from http://reflexologyresearch.net/RWSFullPublishedStudy.pdf

Özköse, A. (2005). The Bathing Tradition in Anatolia. Islamic Urban Heritage, 113. Retrieved from https://www.academia.edu/2998079/The_Bathing_Tradition_in_Anatolia

Parma, G., \& Parmar, M. (2014). Leech therapy - A miraculous treatment. Unique Journal of Ayurvedic and Herbal Medicines, 2(6), 37-39. $\quad$ Retrieved from http://ujconline.net/wp-content/uploads/2013/09/9-UJAHM-14131-Rv.pdf

Qureshi, N. A., Ali, G. I., Abushanab, T. S., El-Olemy, A. T., Alqaed, M. S., El-Subai, I. S., \& Al-Bedah, A. M. N. (2017). History of cupping (hijama): A narrative review of literature. Journal of Integrative Medicine, 15(3), 172-181. https://doi.org/10.1016/S2095-4964(17)60339-X

Raftani, K., \& Radoine, H. (2008). The architecture of the hammams of Fez, Morocco. Archnet-International Journal of Advanced Research, 2(3), 56-68. https://doi.org/10.26687/archnet-ijar.v2i3.282

Ramey, D. W. (2000). A review of the evidence for the existence of acupuncture points and meridians. American Association of Equine Practitioners (AAEP), 46, 220-224. Retrieved from https://pdfs.semanticscholar.org/d920/99deece4ead71a1845cb343b135121955d1c.pdf?_ga=2.200793385.60 7883443.1565273538-510541118.1565273538

Rehman, H., Begum, W., Anjum, F., \& Tabasum, H. (2013). Approach to dysmenorrhoea in ancient ages and its current relevance International Journal of Herbal Medicine, 1(4), 88-91. Retrieved from https://pdfs.semanticscholar.org/f5b2/9293f04accc8d00d69f797eec28bde268ca0.pdf

Reza, M. F., Urakami, Y., \& Mano, Y. (2002). Evaluation of a new physical exercise taken from salat (prayer) as a short-duration and frequent physical activity in the rehabilitation of geriatric and disabled patients. Annals of Saudi Medicine, 22(3-4), 177-180. https://doi.org/10.5144/0256-4947.2002.177

Robinson, N. (2006). Integrated traditional Chinese medicine. Complementary Therapies in Clinical Practice, 12(2), 132-140. https://doi.org/10.1016/j.ctcp.2006.01.006

Round, R., Litscher, G., \& Bahr, F. (2013). Auricular acupuncture with laser. Evidience-Based Complementary and Alternative Medicine, 2013, 984763. https://doi.org/10.1155/2013/984763

Saad, B., \& Said, O. (2011). Graeco-Arab and Islamic Herbal Medicine: Traditional System, Ethics, Safety, Efficacy, and Regulatory Issues. Hoboken, New Jersey: John Wiley \& Sons.

Saeki, Y., Nagai, N., \& Hishinuma, M. (2007). Effects of footbathing on autonomic nerve and immune function. Complementary Therapies in Clinical Practice, 13(3), 158-165. https://doi.org/10.1016/j.ctcp.2006.12.006

Saffari, M., \& Pakpour, A. H. (2012). Avicenna's canon of medicine: A look at health, public health, and environmental sanitation. Archives of Iranian Medicine, 15(12), 785-789. Retrieved from http://www.ams.ac.ir/AIM/NEWPUB/12/15/12/0015.pdf

Saqlain, M., Ali, F., \& Parveen, A. (2017). The value of hijama (cupping) as a therapy in unani system of medicine - With reference to prophetic medicine. World Journal of Pharmaceutical and Medical Research, 3(8), 133-140. Retrieved from file:///Users/ajilatr/Downloads/article_1504229185.pdf

Serageldin, I. (2013). Ancient Alexandria and the dawn of medical science. Global Cardiology Science and Practice, 2013(4), 395-404. https://doi.org/10.5339/gcsp.2013.47

Sherwani, A. M. K., Anasari, A. N., Anasari, H. A. H., \& Anasari, I. A. J. A. (2004). The Contribution of albucasis (abul-qasim zahrawi) in venesection. International Society for the History of Islamic Medicine, 3, 6-8. Retrieved from https://www.ishim.net/ishimj/5/02.pdf

Sherwani, A. M. K., Ahmed, M., Naaz, S. A., Khan, S. A., Sherwani, A. M. K., \& Khan, M. Q. (2006). Balneology: A Concept of Public Health-Bath Houses in Arabian Life. Journal of the International Society for History of $\begin{array}{lllll}\text { Islamic } & \text { Medicine. } & 5, & \text { 15-18. } & \text { Retrieved }\end{array}$ 
https://www.yumpu.com/en/document/read/11456276/balneology-a-concept-of-public-health-bath-houses-i n-arabian-life

Sibley, M. (2008). Editorial: Special issue on traditional public baths- hammams in the mediterranean. Archnet-International Journal of Advanced Research, 2(3), 10-16. https://doi.org/10.26687/archnet-ijar.v2i3.277

Sibley, M., \& Jackson, I. (2012). The architecture of Islamic public baths of North Africa and the Middle East: An analysis of their internal spatial configurations. Architectural Research Quarterly, 16(2), 785-789. https://doi.org/10.1017/S1359135512000462

Sinclaire, M. (2007). Modern Hydrotherapy for the Massage Therapist. Baltimore, MD: Lippincott Williams \& Wilkins.

Singh, A. P. (2010). Medicinal leech therapy (hirudotherapy): A brief overview. Complementary Therapies in Clinical Practice, 16(4), 213-215. https://doi.org/10.1016/j.ctcp.2009.11.005

Sultana, A., Lamatunoor, S., Begum, M., \& Qhuddsia, Q. N. (2017). Management of usr-i-tamth (menstrual pain) in unani (Greco-Islamic) medicine. Journal of Evidience-Based Complementary Alternative Medicine, 22(2), 284-293. https://doi.org/10.1177/2156587215623637

Syed, A. (2003). Spiritual medicine in the history of Islamic medicine. Journal of the International Society for the History of Islamic Medicine, 2(4), 45-49. Retrieved from https://www.ishim.net/ishimj/4/08.pdf

Tan, J. Y., Molassiotis, A., Wang, T., \& Suen, L. K. (2014). Adverse events of auricular therapy: a systematic review. Evidence-Based Complementary Alternative Medicine, 2014, 506758. https://doi.org/10.1155/2014/506758

Tumpa, S. I., Hossain, I., \& Ishika, T. (2014). Ethnomedicinal uses of herbs by indigenous medicine practitioners of Jhenaidah district, Bangladesh. Journal of Pharmacognosy and Phytochemistry, 3(2), 23-33. Retrieved from http://www.phytojournal.com/vol3Issue2/Issue_jul_2014/13.1.pdf

Wardle, J. (2013). Hydrotherapy: a forgotten Australian therapeutic modality. Australian Journal of Medical Herbalism, 25(1), 12-17. $\quad$ Retrieved from http://www.natural-knowhow.com/home/wp-content/uploads/2015/01/Hydrotherapy-article.pdf

Yamamoto, K., Aso, Y., Nagata, S., Kasugai, K., \& Maeda, S. (2008). Autonomic, neuro-immunological and psychological responses to wrapped warm footbaths--a pilot study. Complementary Therapies in Clinical Practice, 14(3), 195-203. https://doi.org/10.1016/j.ctcp.2008.04.001

Zargaran, A., Zarshenas, M. M., Karimi, A., Yarmohammadi, H., \& Borhani-Haghighi, A. (2013). Management of stroke as described by Ibn Sina (Avicenna) in the canon of medicine. International Journal of Cardiology, 169(4), 233-237. https://doi.org/10.1016/j.ijcard.2013.08.115

\section{Appendix}

\begin{tabular}{lll}
\hline $\begin{array}{l}\text { Applied } \\
\text { Therapy }\end{array}$ & Indications & Notes \\
\hline Leeching & $\begin{array}{l}\text { Varicose veins, chronic skin disease, chronic ulcers, } \\
\text { musculoskeletal and cardiovascular conditions. }\end{array}$ & $\begin{array}{l}\text { Advised on areas of the body where } \\
\text { othesses of bloodletting like } \\
\text { venesection and cupping are not } \\
\text { possible. }\end{array}$ \\
\hline Venesection & $\begin{array}{l}\text { Removing excess humors, stimulating metabolic processes and } \\
\text { correcting altered temperaments. }\end{array}$ & $\begin{array}{l}\text { Practice of venesection was seemingly } \\
\text { put to an end by the Prophet Muhammad } \\
\text { (PBUH). }\end{array}$ \\
\hline Cauterization & $\begin{array}{l}\text { Epilepsy, headache, toothache, depression, hemorrhoids, } \\
\text { paralysis, recurrent cold and cough, migraine, musculoskeletal } \\
\text { disorders, vascular bleeding, gangrene, moles, skin outgrowths, } \\
\text { splenomegaly and ascites. }\end{array}$ & $\begin{array}{l}\text { Prophet } \\
\text { cauterization only in severe cases }- \text { a } \\
\text { position that has since been maintained } \\
\text { in Islamic law. }\end{array}$ \\
\hline
\end{tabular}


Asthma, dyspnea, migraine, palpitation, chronic pain including headache, knee \& low back pain, hemorrhoids, amenorrhea, renal and ureteric colic, plethora, pustules Cupping and boils, sciatica, gout, diseases of the liver, spleen and psoriasis, etc., excessive menstrual bleeding, removal of deep swelling, scrotal hernia, sciatica, piles, hydrocele, gout, renal calculi and epistaxis.

\begin{tabular}{ll}
\hline $\begin{array}{l}\text { Manual Therapy } \\
\text { - Therapeutic Massage }\end{array}$ & $\begin{array}{l}\text { Musculoskeletal and chronic pain, weight management } \\
\text { and psychosomatic disorders. }\end{array}$ \\
- Reflexology & Chronic pain, insomnia, sexual dysfunction and stroke. \\
- Bone Setting & Dislocated or fractured bones.
\end{tabular}

\begin{tabular}{ll}
\hline Auricular Therapy & $\begin{array}{l}\text { Contraceptive, sciatic pains, sexual dysfunction, } \\
\text { generalized pain. }\end{array}$
\end{tabular}

Fomentation Local swelling and pain, sinusitis, bloating, as analgesic and muscle relaxant.

Reduce viscosity of the humors, promote circulation,

Hydrotherapy

- Hammam

- $\quad$ Sitz bath improve metabolism and overall health, promote detoxification, weight management, strengthens vitality.

Activates the internal organs of the abdomen and pelvis by increasing blood circulation to the surfaces and reduces congestion of muscle and inflammation.

- Hand \& Foot bath

- Vaporization, Steam \& Aromatherapy

Relieves stress, combats fatigue and insomnia symptoms in addition to increasing overall body temperature and white blood cell activity.

Colds, flu, acne lesions, paralysis, nervousness, muscle pain and as a freshener.

Enhance the vital force of the body, and eliminate waste products.
Prescriptions refer to certain days of the lunar calendar as well as specific sites on the body including head, back and shoulders.

A variety of techniques exist and utilized according to condition.

Herbal therapy and oils often accompanied method.

Specific plants and dietary practices are utilized as an adjunct to the treatment.

Ear was pricked with a needle or cauterized with heat.

A variety of techniques exist and utilized according to condition, herbal remedies or oils accompanied method.

Historically facilitated the accomplishment of the great ablutions necessary prior to praying.

Used as a means to deliver local application of herbal medicines.

Oils, herbal extracts or decoctions are used in conjunction with the bath.

Method often relied on therapeutic oils.

Intensity, timing and the conditions are all specified, as is the manner of their application.

\section{Copyrights}

Copyright for this article is retained by the author(s), with first publication rights granted to the journal.

This is an open-access article distributed under the terms and conditions of the Creative Commons Attribution license (http://creativecommons.org/licenses/by/4.0/). 